\title{
FIELD REVIEW OF FISH HABITAT IMPROVEMENT PROJECTS IN CENTRAL IDAHO
}

\author{
Prepared by: \\ Robert L. Beschta, Phd \\ Jack Griffith, Phd \\ Thomas A. Wesche, Phd
}

Prepared for:

U. S. Department of Energy

Bonneville Power Administration

Division of Fish and Wildlife

P.O. Box 3621

Portland, OR 97283-362 1

Project Number 84-24; 83-359

Contract Numbers:

DE-AP79-92BP6 1032

DE-AP79-92BP6 1034

DE-AP79-92BP6 1039

MAY 1993 


\section{FIELD REVIEW OF FISH HABITAT IMPROVEMENT PROJECTS}

IN CENTRAL IDAHO

\section{INTRODUCTION}

The goal of this field review was to provide information to the Bonneville Power Administration (BPA) regarding previous and ongoing fish habitat improvement projects in central Idaho. On July 14, 1992, the review team met at the Sawtooth National Recreation Area office (SNRA) near Ketchum, Idaho, for a slide presentation illustrating several habitat projects during their construction phases. Following the slide presentation, the review team inspected fish habitat projects that have been implemented in the last several years in the Stanley Basin and adjacent valleys. At each site the habitat project was described to the field team and a brief period for project inspection followed. The review team visited approximately a dozen sites on the Challis, Sawtooth, and Boise National Forests over a period of approximately two and a half days.

There were two objectives of this review: (1) to summarize observations for specific field sites and (2) to provide overview commentary regarding the BPA habitat improvement program in central Idaho. 


\section{CONCLUSIONS AND RECOMMENDATIONS}

It is unfortunate that so many enhancement projects in the Columbia Basin have been undertaken with minimal or no funding available for monitoring and evaluation (M\&E). Without a significant level of M\&E, the public may never know whether BPA funding of fish habitat projects has significantly benefited, had little impact, or has negatively affected the potential recovery of anadromous fish stocks in central Idaho. A rigorous M\&E effort is desperately needed. A benefit-cost analysis for various projects would also be useful.

Many of the projects that were reviewed involved a blending of private, BPA, Idaho Fish and Game, and US Forest Service efforts. We encourage and are supportive of such cooperative endeavors. However, it was unfortunate that Idaho Fish and Game representatives were unable to participate in the field review; their comments, insights, and perspectives would have been useful and instructive to the review team.

Irrigation diversions can have potentially disastrous consequences for migrating salmonids (both upstream adults and downstream smolts). Efforts to limit these consequences through diversion structures that insure both the passage of fish and unclaimed flows need to be continued. The Valley and Knapp Creek projects were well designed and constructed to meet these important objectives. In these instances, additional flows became available to the main stream after a diversion structure had been modified or installed. Such projects should be designed to cause the minimum amount of impacts to channels and streamside vegetation.

As in many areas of the West, historical dewatering of channels has had adverse impacts to fisheries: loss of access to upstream spawning and rearing habitat, loss of downstream migration routes, loss of spawning and rearing habitat in the dewatered sections of a stream, and a general increased fragmentation of fisheries resources. The restoration of 
sustainable flows in previously dewatered channels should be a high priority. Without continuous flows, any hope for improved fisheries is ultimately destined to fail.

BPA funds are being used to address a wide array of important habitat problems. However, an inordinate proportion of the overall $\$ 600,000$ Yankee Fork Project cost was apparently spent on engineering analysis and design for a relatively simple project, i.e., the connecting of individual ponds with simple channels and the connecting of pond complexes with the stream. In retrospect, a less "sophisticated" and less costly design approach could have been undertaken that would have allowed additional money for enhancing individual ponds and for an expanded monitoring and evaluation effort, so that fish population dynamics and productivity could be better understood.

The use of mixed genetic stocks to reestablish or augment native fish populations (e.g., Yankee Fork ponds) should be abandoned. Outplantings should be limited in scope and only locally adapted stocks should be used for future outplanting projects.

The Yankee Fork Project is not operating at potential. Modification of unvegetated banks to improve riparian/aquatic interactions along pond margins should be undertaken. The full flow available for each pond series should also be utilized. Additional monitoring is needed to further refine the smolt producing capability of these ponds.

The Stanley Creek riparian pastures are too small to provide important fisheries information. However, such studies need to be continued and the results periodically summarized to demonstrate changes in channel morphology and riparian vegetation for various grazing systems.

Marsh Creek and Elk Creek represent important unconstrained stream systems with high potential for fish habitat 
improvement. Riparian vegetation is generally becoming well established along Marsh Creek and additional rest from grazing will allow continued recovery. Elk Creek is much more degraded: streamside vegetation has been severely impaired, streambank erosion is widespread, channel morphology has been adversely affected, channel incision continues to hydrologically disconnect the stream from former floodplains (i.e., desertification of riparian systems), and stream substrate conditions are generally undesirable for fisheries. Current efforts at providing "organic riprap" or tree revetments (junipers or firs along the banks with single rail fences for grazing protection) at selected sites is not addressing the primary problem with this stream. Although organic riprap can provide improved opportunities for establishing streamside vegetation, restoring bank stability, and providing important instream cover for rearing salmonids, such treatments represent stopgap efforts. They should not be utilized as a means of neglecting management practices currently affecting stream and riparian system degradation. Elk Creek requires rest from grazing impacts via fencing or other management methods that fully protect streamside vegetation. Grazing should be reconsidered only after longterm rehabilitation of the riparian system and its stream. Even then, the highest priority of a grazing management strategy should be the establishment, growth, and succession of riparian vegetation. The existing Allotment Management Plan should be revised immediately and should carefully consider Elk creek's current degraded condition.

Prior to the use of structural treatments (rock weirs, riprap, boulder placements) for arresting local bank or channel erosion, the long-term effects of such actions need to be considered. Although structures may be used to effectively stop a local sediment source (e.g., Bearskin Oxbow cutoff), the consequences of lost channel sinuosity and increased gradient are generally detrimental to the maintenance of a productive fisheries. The desire to structurally "constrain" streams located in geomorphically "unconstrained" valley locations 
should seldom be undertaken. Furthermore, the amount of sediment that is prevented from entering such a heavily impacted stream as Elk Creek may be of little consequence in relation to other factors, such as grazing, that are affecting the stream and its riparian vegetation.

Habitat improvement projects undertaken on large streams or rivers need to develop background information on hydrology and geomorphology. For example, historical peak flow records (and water levels associated with these peak flows) should be analyzed for any stream gages in the vicinity and used for project planning purposes. Where extensive channel alterations are planned via habitat enhancement operations, systematic evaluations of stream gradients, sediment budgets (where appropriate), and other geomorphic information could provide an important context for better understanding the appropriateness of a particular project and the specific design features of that project.

The appropriateness of undertaking channel and bank stability projects on private lands should be carefully considered. For example, considerable fisheries enhancement dollars were spent for a cooperatively funded project along the salmon River to improve salmon habitat and prevent additional bank erosion of private lands. While stabilizing accelerated bank erosion for private land owners may seem laudable, it may represent an ineffective use of BPA monies. However, if such projects obtained, for example, public access for fishing as part of the channel stabilization effort, the expenditure of large amounts of funds would be better justified.

The inexpensive cost of placing boulders in a channel is not adequate justification for revamping the geomorphic character of a stream reach. For example, at the Decker Flat Diversion structure, where a close and inexpensive source of rock was available, large numbers of boulders were placed in the channel--many more than originally planned. Considering that these structures are located in the midst of the Sawtooth 
National Recreation Area, which has a strong emphasis on maintaining natural features and values, the magnitude of this project is out of character with other management goals. Just because boulders are inexpensive to place and fisheries is an important management issue is not license to revamp the geomorphic and aesthetic character of a river.

Most of the channel modifications for fish habitat enhancement that were visited by the review team were done within the last several years and have not yet experienced large flow events. Hence, the long-term consequences to channel morphology are not known and should be evaluated in the future.

We were encouraged by the diversity of approaches utilized to improve habitat conditions for anadromous fish in central Idaho. Such diversity in attempted solutions also indicates the wide range of factors that have historically affected fisheries habitat: mining, grazing, streamside roads. The application of alternative approaches is due in no small way to the involvement of John Andrews. We were impressed by his desire to do what was best for the stream and by his continuous consulting with specialists from other disciplines to obtain insights, comments, opinions, and alternative perspectives on proposed projects. Such adaptive management is to be commended.

We were also encouraged that "real" fish habitat problems were being addressed. Although the review team may not fully agree with all solutions employed, we are hopeful that significant gains are being made to improve anadromous fish habitat in central Idaho. We expect that restoration strategies and projects will be further improved if increased emphasis on ecosystem perspectives--a full understanding and appreciation of geomorphic context and riparian functions--are incorporated into future activities. 


\section{SITE COMMENTS}

At each field site, personnel familiar with a particular project (BPA representative, US Forest Service, or private landowner) briefly described the overall setting, management history of the area, pre-project fisheries concerns, and general characteristics of each implemented project. The brief amount of time spent at each site generally allowed only inspection of the immediate project and often precluded inspection of upstream or downstream conditions. Hence, specific observations, interpretations, and comments herein are not necessarily representative of entire stream reaches, but only of those sections observed by the review team.

\section{Site \#1 \\ DREDGE PONDS, YANKEE FORK (Shoshone-Bannock Tribe Project)}

(July 14, 1992)

\section{Site Description}

In the 1930s and 1950s, the Yankee Fork stream and associated valley bottom was mined by a floating dredge. Following mining, dredge piles were left along the valley with several complexes of ponds. After an extensive design study, a project was initiated that connected the dredge ponds with the Yankee Fork by means of small channels in order to improve chinook salmon rearing habitat. A total of 16 ponds, with four ponds in each in four series, have been hydrologically "connected" to the main channel. Water is diverted from the Yankee Fork at the head of each pond series through a 36 inch culvert, with additional inlet and outlet structures (for regulating flows and keeping fish populations separated) associated with most of the ponds. Splash boards are inserted in the flow control structures during periods of high stream flow to limit flows into the ponds. Each pond series apparently has a 5 cfs (cubic feet per second) water right. However, for some ponds, subsurface flows are undoubtedly an important source of water. 
Surface water elevations in the ponds generally vary less than 6 inches.

Construction activities, which consisted primarily of developing channels to provide hydrologic connections between the ponds and the Yankee Fork, occurred in 1987 and 1988, followed by planting of willow cuttings (with approximately 75\% survival). Approximately $\$ 600,000$ was spent on design, construction, and planting activities. Fish studies have been undertaken to evaluate relative use and productivity of various pond series.

Since construction, a series of mixed stock fish outplantings have been undertaken and fish migration has been monitored in an attempt to better understand the factors affecting habitat utilization and survival. Considerable migration of outplanted fish has occurred, particularly during periods of high flow.

Individual ponds are generally deep (6 to 12 feet), steep sided, and lacking in cover. There is little open-water use by juvenile fish. Where juniper trees have been added, fish apparently utilize this cover. At Pond Series \#l, beaver have occupied several channels, connecting individual ponds, and are affecting flows between individual ponds. Steep north facing banks in Pond Series \#l are largely unvegetated. Pond Series \#2 banks are generally vegetated with alder and some lodgepole pine. Pond Series \#2 was relatively productive when stocked with outplanted chinook salmon.

\section{Observations/Interpretations/Comments}

Based on the 1989-90 annual reports, the Yankee Fork ponds provide important salmonid smolt production. Continued monitoring of fish movement and production should occur to help refine the current understanding of the potential for these ponds to provide additional off-channel spawning and rearing habitat. 
The use of mixed stocks may have a large, but unknown, effect on fish use and productivity from the pond series; therefore, the use of various stocks for outplanting in the Yankee Fork ponds should not be continued. A locally adapted stock should be selected for future outplantings and utilized exclusively.

A primary objective of future pond operations is to operate with as little human intervention as possible. Thus, any structural alterations to the main Yankee Fork channel at the inlet of a pond series (Pond Series \#2 is especially in need) should attempt to provide a sustainable flow of up to $5 \mathrm{cfs}$. Furthermore, the potential effects of these diversions on fish movement into and out of a pond series should be considered.

Many of the ponds have relatively steep banks of dredge spoils that lack vegetation cover. This condition limits ecosystem process (nutrient cycling, carbon inputs, shading, large organic debris recruitment) which are known to have important direct and indirect effects on fish habitat productivity. Where vegetation is lacking, slopes (particularly along the edges of the ponds) should be mechanically flattened to provide greater amounts of shallow water habitat and to create soil surfaces in close proximity to subsurface water levels. Revegetation of areas above the water line should also be attempted with willows, alder, and conifers in an attempt to initiate the establishment of shrub and tree species. Because fish are apparently utilizing what little large organic debris that has been added along the pond margins, the establishment of trees along pond margins should be an important immediate goal that may provide long-term benefits to fisheries.

The construction of concrete control structures with splash boards provides a direct means of controlling flow and fish movements from the ponds. However, after the completion of ongoing fish studies, the removal of these structures is desirable. These structures tend to trap and accumulate floatable organic debris. Hence, partial or complete removal 
of these structures may reduce their potential to block fish migration.

Beaver dams currently affect flow conditions between ponds for portions of Pond Series \#l. These ponds are increasing inchannel depths and the amount of water contact with edge habitat and wetland vegetation. Although beaver activity may sometimes alter the ability of fish to move from pond to pond, we view their activity as an important component of a functioning stream and riparian system and suggest that they not be removed from the channels connecting pond series.

In retrospect, the high expenses incurred for designing relatively simple treatments (e.g., the connecting of pond series with channels) do not seem warranted. Apparently half of the total project cost of $\$ 600,000$ was used for design purposes. Much of this money might have been better spent for (1) continued monitoring of fish responses to various environmental conditions in the ponds, (2) adding woody debris cover, especially to the center portions of the larger ponds, (3) reworking the entrance to the pond series to allow more drift of fish to enter from upstream, (4) sloping or benching steep mine spoil piles along the edges of the ponds, or (5) initiating plantings on the barren mine spoil slopes that border many ponds. In 1992 the ponds were not being operated to maximize fish production. Although the Shoshone-Bannock tribes have done a good job of undertaking a preliminary evaluation of pond production, it is important that such knowledge be put into practice.

It may be necessary to improve entrance conditions from the main channel to some pond series. For example, the culvert screen at the upstream inlet to Pond Series \#2 was plugged with fine debris. Flow conditions and slow stream velocities near the diversion probably prevent fish drifting downstream from entering this pond series. The mainstream thalweg was some distance across the channel from where water was diverted into the pond series. Thus the main channel approach to this 
diversion may need to be modified to bring deeper and faster flowing water closer to the diversion inlet. The exposed diversion channel may also contribute to high predation and banks need to be revegetated. Although 5 cfs could be legally diverted into each pond series, flows of this magnitude were not flowing in the diversion channels during the field review.

The ongoing studies associated with Yankee Fork ponds have provided important information about how habitat is being utilized. Such studies need to be continued until the productive potential of these habitats is more fully understood. Continued efforts should be made to obtain Salmon River (Sawtooth Hatchery) chinook salmon for planting in the pond series; Rapid River fish should not be utilized.

\section{Site \#2 RIPARIAN PASTURES, STANLEY CREEK} (July 15, 1992)

\section{Site Description}

The Stanley Creek drainage received heavy grazing pressure in the late 1800s and also during World War I. Since 1987 a reach of Stanley Creek has been subdivided into riparian pastures to study the effects of grazing. Grazing occurs in late June/early July and several levels of riparian plant utilization ( $0 \%$, 30\% and 60\%) are being tested. A small section of channel upstream of the study area that was excluded from grazing in 1991, has experienced dredging impacts (channel realignment, dredge spoils, etc.). Both steelhead and chinook salmon can potentially use Stanley Creek.

The current channel is incised approximately 3 feet or more below the historic valley floodplain surface. The depth of incision appears to increase in a downstream direction. Soils comprising the old floodplain are generally mottled below the A horizon and gleyed at depth, indicating the valley bottom 
originally supported an extensive wet meadow. Deposits of up to 8 inches of sand sized particles commonly occur on top of a silty textured meadow soil at various locations along the existing channel. Snowmelt runoff has generally been below normal since this study began and high flows have not occurred.

\section{Observations/Interpretations/Comments}

Channel incision in floodplain systems due to past grazing and landuse activities is a common feature of many western streams. Once initiated, channels tend to downcut until they encounter a confining layer or relatively large bed material. Following channel incision, channel widening occurs and a new floodplain develops below the previous floodplain surface. Without adequate vegetation cover, reestablishing streambank stability may not occur. This general scenario seems to have occurred along this reach of Stanley Creek.

Because the grazing study has only been underway for a few years and there have been no significant high flows, the effects of different treatments have not yet been demonstrated. Nevertheless, the increasing presence of willows, particularly in those sections of stream totally excluded from grazing is encouraging. Exposed and eroding banks are less common in the ungrazed sections and the trapping of finer textured sediments is more prevalent than in reaches being grazed at 30 or 60 percent. However, even without grazing, bank-building processes occur slowly for such streams in this portion of central Idaho. Continued vegetation recovery and decreased bank erosion should provide the context for evaluating the relative success of these treatments. The pastures are generally too small to provide much opportunity for assessing fisheries impacts or improvements.

A reach that had been dredge mined was excluded from grazing in 1991 and is experiencing a rapid establishment of willows. Remnant dredge ponds are developing into well vegetated wetlands and off-channel habitat. Because of the dredging 
effects, this section of channel has a relatively high sinuosity and channel complexity. Further recovery of the vegetation along this reach may make this a valuable section for spawning and rearing habitat.

We were not given adequate information (length of study, number of spawning salmon, fish densities, etc.) to do a serious evaluation of this study regarding fisheries resources. However, we recommend this study be continued and that attempts be made to assess fisheries benefits.

Site \#3

IRRIGATION DIVERSION NO. 6, VALLEY CREEK

$$
\text { ( July 15, 1992) }
$$

\section{Site Description}

Historically, Water Diversion No. 6 on Valley Creek diverted all flows during certain portions of the year and effectively blocked the upstream or downstream migration of fish. In 1988 a rocked diversion structure was installed and additional rock work was done in 1990 to provide hydraulic control of flow diversions. In doing so, unclaimed flows could continue down the main channel and sustain Valley Creek. By maintaining continuity of flows at this diversion, an additional 9 miles of upstream spawning and rearing habitat for anadromous fish were made available. The first year after construction, 30 redds were observed upstream; last year 5 redds were observed.

\section{Observations/Interpretations/Comments}

The major advantage of the constructed diversion is that it eliminates the need to annually alter the channel with equipment to create an inchannel berm for diverting irrigation flows. By having this permanent control structure, the land owner is insured of obtaining legal flows yet any excess is 
bypassed to the main channel. The observation of redds upstream attests to the general success of this treatment.

The advantages of using large rock versus concrete for such diversions was discussed. Although concrete structures can be more precisely designed, the current structure provides an adequate means of diverting any specified flow. Because it is constructed of native materials, it has a more natural appearance than would generally be achieved with concrete. In addition, the potential for structure modification (through the placement or removal of selected rocks) makes this structure adaptable to future changes in stream conditions. Concrete structures would have little such flexibility for modification.

Although the diversion structure has not been "tested" by high flows, the size of rock used was sufficiently large that it will likely withstand the effects of high flows. The planting of willows (entire plants with root masses) at selected streambank locations was undertaken following construction to provide bank stability. This procedure represents a sound technique for rapidly reestablishing bank stability.

Access to this site across a dry meadow should be prohibited because of potential impacts to meadow vegetation.

\section{Site \#4 \\ IRRIGATION DIVERSION, KNAPP CREEK}

(July 15, 1992)

\section{Site Description}

In 1987 a rock diversion structure with bypass channel was installed in Knapp Creek. Its purpose was to provide upstream access to several miles of spawning and rearing habitat for anadromous fish. The existing wooden diversion structure was blocking upstream migration. Because the constructed diversion was located upstream of the existing wooden structure, a bypass 
channel was needed to allow the movement of upstream adults and downstream smolts past the existing wooden structure. The bypass channel was constructed though a meadow and incorporated several rock structures to prevent channel downcutting.

Willow cuttings were planted along the constructed bypass channel. Although many survived, their growth appears to be slow and the channel currently lacks cover. The bypass channel is experiencing minor amounts of erosion between structures.

\section{Observations/Interpretations/Comments}

The constructed diversion structure seems to work well and allows adults to pass upstream. The new channel provides some rearing habitat for chinook and steelhead, but there was a general abundance of such habitat in the immediate vicinity. The project has high potential fisheries benefits if spawners were not previously able to use areas above the diversion. Furthermore, the bypass prevents potential conflicts with water users regarding operation of the wooden diversion structure.

\section{Site \#5 \\ RIPARIAN PASTURE, MARSH CREEK \\ (July 15, 1992)}

\section{Site Description}

The Marsh Creek Pasture occupies approximately 600 acres at 6,800 feet of elevation. Approximately 20 years ago, this pasture was grazed annually by 350 cattle. Today, 175 cattle utilize the pasture for 2 months from mid-July to september with approximately 40\% utilization. Approximately 40-50\% of the stream currently has stable banks with a long-term goal of attaining 85-90\%. The preferred alternative for this pasture in the Forest's EIS is total exclosure. 


\section{Observations/Interpretations/Comments}

Marsh Creek occupies an active braided channel in the middle of the pasture. Revegetation of the banks appears to be occurring and should be encouraged. The total removal of grazing pressure would be the most effective means of insuring the rapid restoration of riparian vegetation.

\section{Site \#6 \\ BANK EROSION PROJECT, ELK CREEK}

(July 15, 1992)

\section{Site Description}

The outside bank of an eroding meander was treated with juniper in 1988 and a single pole fence constructed to locally control grazing effects at this meander. Although juniper were used at this site, subalpine fir (up to 25 feet in length) are apparently being used at other locations in the drainage. The current grazing program utilizes Elk Creek for two weeks early in the season; this grazing pattern was initiated last year. The sand bed channel, eroding banks, and lack of vegetation cover along many of the channel banks are indicative of a degraded stream system.

\section{Observations/Interpretations/Comments}

As a result of historic grazing practices, and possibly other land use activities in the watershed, the channel along much of Elk Creek is actively eroding. Whether the newly implemented grazing practices will allow recovery is problematic. Although the juniper riprap may have stabilized the bank that was visited in the field, the general channel incision and continued loss of valley bottom soils by channel erosion needs to be stopped as soon as possible. The effects of stream incision are also becoming evident along the valley soils which were former floodplains for Elk Creek. For example, in former 
wet meadows (indicated by the extensive mottling of soils immediately below the A horizon) gophers are now common. Sedges and willows appear to be decreasing and are being replaced by more xeric species. These indicators point to a stream and valley system that has been greatly altered because of past management.

Grazing has had a major impact on soil resources, fish habitat, riparian vegetation, and wildlife habitat. As long as grazing impacts continue, the full potential of the bank treatment will not be realized by the fishery. A few juvenile chinook were using cover provided by the junipers, but most of the stream margin was too shallow to be used. While the treated bank will probably become more stable, deepening along this margin will not be permanent unless sediment loading is reduced. To improve riparian vegetation and stream habitat, grazing needs to be reduced or stopped until recovery is achieved.

\section{Site \#7 \\ BEARSKIN OXBOW CUTOFF, ELK CREEK}

(July 15, 1992)

\section{Site Description}

At this site, Elk Creek had been actively eroding into a glacial terrace comprised of predominantly sand-sized sediments. Nearly 20 feet of lateral erosion into a lo-foot high terrace along approximately 300 feet of channel had released an estimated 2,500 cubic yards of sediment into Elk Creek over a 3-year period. Continued bank erosion was anticipated and thus this project was initiated for the purpose of stopping additional erosion.

The project consisted of constructing a meander cutoff and stabilizing the new channel with rock weirs and riprap. Approximately 500 feet of a meander was replaced with 100 feet of steeper gradient channel associated with the rock weirs. 


\section{Observations/Interpretations/Comments}

If bank stability is the primary criterion for evaluating this project, it would be considered a success. The rock weirs and riprap, as installed, have stopped stream erosion of the glacial terrace. However, in the context of fluvial processes and riparian system dynamics, this project has largely prevented the channel from adjusting to changing flow/sediment loads and its interaction with riparian vegetation. From a long-term perspective, the project has changed this reach from an "unconstrained" to a "constrained" system. Unconstrained streams are geomorphically complex, have more diverse riparian plant communities, and are typically more productive for fisheries than are constrained reaches. The installed structures have largely eliminated potential channel adjustments in conjunction with riparian vegetation. Although nearly 500 feet of former channel is now providing some rearing habitat, through time infilling will sever it from the main stream.

Sediment influx from an eroding glacial terrace may initially seem to represent a major problem, however it probably comprises only a small portion of Elk Creek's total sediment load. Furthermore, the control of this sediment source has done little to alleviate the channel instabilities observed farther downstream. The management emphasis on this site, and on other bank erosion projects utilizing juniper stabilization techniques, should only be coupled with better grazing management to more thoroughly address Elk Creek's problems. Other important uses for these funds would have been for improvement of forage elsewhere on the Forest, for exclosure fencing along the stream so that cattle grazing can be eliminated from the stream and riparian systems of Elk Creek, or for the conduct of education programs which demonstrate to producer groups the benefits of improved riparian management. 


\section{Site \#8 \\ EROSION CONTROL PROJECT, DRY MEADOW CREEK}

(July 15, 1992)

\section{Site Description}

In 1990 a series of low rock check dams were installed along more than a mile of eroding channel. The erosion from this intermittent stream channel apparently represented a major source of sediment in the drainage.

Dry Meadow Creek flows along the eastern edge of a "dry" meadow. Exposed soils along cut banks were coarse textured, porous, and had none of the indicators of typical "wet" meadow conditions. Volunteer lodgepole pine were becoming established in portions of the meadow, indicating dry site conditions. The erosion and downcutting of Dry Meadow Creek has probably contributed to a lowering of water tables along the eastern side of the meadow.

\section{Observations/Interpretations/Comments}

The structural treatments appear to have arrested channel headcutting and continued erosion of Dry Meadow Creek. This project should help rehabilitate fish habitat in Elk Creek by reducing sand bedload influxes, although we did not view the downstream reaches.

Vegetation establishment that is occurring within the eroded channels will continue to be slow because of the harsh site conditions. Continued revegetation of exposed soils and the protection of vegetation near the upstream headcuts of Dry Meadow Creek are a high priority. Grazing should be reduced or temporarily eliminated on Dry Meadow Creek and its riparian system to allow recovery of vegetation.

A small number of adult brook trout were observed in the upper end of the project area. Although these trout were using 
habitat created by inchannel structures, due to a lack of riffles for invertebrate production they were literally starving to death.

\section{Site \#9 \\ HANSON'S LANDING BANK EROSION PROJECT, SALMON RIVER}

(July 16, 1992)

\section{Site Description}

Riprapping was undertaken by the Idaho Highway Department to protect the roadway from the erosive effects of high flows that have caused the channel to locally deepen. Continued deepening of the channel could cause an initiation of headcutting and a progression of channel incision in an upstream direction. Farther downstream, the channel had widened and became braided. In an effort to improve the stability of this reach and to provide improved resting habitat for migrating adult salmon, two "barbs" (slanting rock sills that extend out into the channel with their highest elevation along the bank and their lowest elevation located upstream and at approximately midchannel) were installed along the upstream end of this reach where the river came into contact with the highway riprap. A low rock sill, consisting of boulders 2.5 to 3 feet in diameter, was also constructed across the channel at the downstream end of this reach.

Some fisheries monitoring had been undertaken for this site. However, the data had apparently been misplaced and were not available for the review team.

\section{Observations/Interpretations/Comments}

The installation of the two barbs should provide additional protection to the highway and may prevent additional channel headcutting or incision. Although some bank erosion has occurred upstream of the uppermost barb, the bank appears to be 
stabilizing. Similarly, the rock weir may be contributing to the stability of the channel and assisting in the stabilization of the downstream braided reach. Excellent adult salmon holding water currently exists below the upper barb. However, because of their relatively recent construction, the hydraulic effects of these structures on channel geometry and fluvial processes over a range of flows, particularly high flow events, have not been "tested".

\section{Site \#10 \\ REMBER/MASSEY CHANNEL STABILITY PROJECT, SALMON RIVER}

(July 16, 1992)

\section{Site Description}

At this site the Salmon River was actively eroding the prehistoric floodplain and valley sediments. Channel widening was occurring at a rapid pace and essentially excavating private land along the east side of the river. In 1988 a low rock weir was extended across several braided channels in an attempt to stop bank erosion and braiding of the river. This effort was also an attempt to recover deep holes for adult salmon holding along the west side of the valley where the river formerly flowed along relatively large cobble and boulders that represented natural armoring of stable glacial deposits.

Farther upstream of the low rock weir, several barbs were constructed in an attempt to stop bank erosion along the east side of the river. Conifers were also cabled along the bank.

\section{Observations/Interpretations/Comments}

The top of the low rock weir was generally at the same elevation as existing bed elevations. This "low profile" approach to weir construction is commendable. Once vegetative 
recovery is well underway, it is possible that the weir will largely disappear or be buried by bed material.

Considerable amounts of fisheries money are being spent at this location, primarily, in our estimation, in an attempt to slow the erosion of private lands. In instances such as this, a land purchase should be pursued before any channel alterations are considered. The use of public funds to help stop private land erosion may not be justified, particularly if management practices by the landowner were responsible for creating the original channel instabilities. Where public monies are spent on

private lands, even if some private funds were used for project design or construction, public access for fishing purposes should be negotiated as part of the project.

Mid-channel bars through the braided reach had surface elevations equivalent with prehistoric floodplain surfaces. This situation indicated that significant amounts of sediment were coming from upstream locations. Although the existing project may stabilize the channel, a systems perspective of sediment sources, transport, and deposition along the salmon River was not evident. Hence, it was not known whether the problems associated with the Rember/Massey project existed in other areas, or whether these were the most pronounced problems along the river. Although the short-term objectives may well be obtained by the types of structures currently being employed at this site, of more important concern are the long-term ramifications of converting "unconstrained" sections of river into relatively "constrained" reaches. What are the fisheries consequences of continued installation of structural controls along the Salmon River? When will structural approaches no longer be necessary or has a process been started that guarantees the long-term "structuring" of the river? What are the cumulative effects to channel dynamics of continued structural additions along these reaches of the Salmon River? In the brief time allotted for the field review, the review team was not able to secure answers to these questions. 
However, the team did conclude that the overall spatial and temporal context of channel and sediment dynamics of the Salmon River had not been systematically evaluated. Such a study should be conducted before other projects are initiated. Without this context, the piecemeal application of structures cannot be adequately assessed.

Excellent rearing habitat occurred in the cover associated with the conifers cabled to the right bank. This also represents valuable winter habitat for juvenile salmon. The fish habitat created by this cover is vastly superior in quantity and quality to that which would have been produced from merely riprapping the right bank. Adult salmon holding habitat was established in two deep pools along the left bank.

\title{
Site \#11
}

DECKER FLAT DIVERSION, SALMON RIVER

\author{
(July 16, 1992)
}

\section{Site Description}

Prior to implementation of this project, there apparently was approximately a 4 foot drop in the channel near the diversion with no resting pools downstream.

Built in 1990, nearly 1600 cubic yards of rock were placed at several locations along the river bed to create a stable diversion structure that did not require annual maintenance and would allow passage of adult salmon and to provide resting pools. Because the source of rock was close, the placement of large volumes of material was undertaken at relatively little expense. Six major rock weirs were placed along the river, each weir 0.7 foot lower in elevation than its upstream neighbor. Individual rocks were about 3 to 4 feet in diameter and were generally larger than other boulders observed along the channel; hence, their stability seems assured. 


\section{Observations/Interpretations/Comments}

Adequate adult salmon holding habitat is now present along this reach. Although juvenile rearing habitat was also present, more (and better) habitat could have been provided if large wood was placed along pool edges where summer depth was about two feet and moderate flow velocities were present.

The rock structures have greatly increased the "stability" of the Salmon River through this reach. However, the massive amounts of rock that were placed seem totally out of context with the project's first objective. Certainly a main channel control structure could have been installed without the necessity of the additional and relatively large rock structures that continue downstream. The massive amounts of rock added to the river seem to be entirely out of context with the intent of the Sawtooth National Recreation Area (SNRA). It seems implausible that this project could have been approved by the USDA Forest Service within the SNRA guidelines of assuring "...the preservation and protection of the natural, scenic, historic, pastoral, and fish and wildlife values..." Insuring the survival of native fish runs is of paramount importance in the Stanley Basin, but the magnitude of rock additions employed in this project raises the question--what are the limits to channel alteration allowed for fisheries habitat modification? The Bonneville Power Administration needs to address such issues regarding their policies for fish habitat projects.

This project seems to typify the American adage "if some is good, then more is better." The review team did not know what the original project designs specifically called for at this reach, but the relatively low costs of procuring and placing rock apparently allowed the amount of material utilized to be greatly increased. The question has to be asked: "Is more rock better?"

The second objective of this project was to provide holding pools for migrating adults. Large pools are currently present 
below most of the six structures. However, the structures have only been in place since 1990 and have not yet experienced a significant peak flow. Thus the ability of these pools to sustain themselves is not known. In fact, the pool created between the uppermost structures is filling with sediment. The long-term prognosis for these structures may well be that limited amounts of holding water will be available as these pools begin to fill with bed material. An important monitoring project here would be a simple profiling of stream bed elevations between each structure to track the rate and extent to which the existing pools fill with bed material.

\section{Site \#I2 \\ EROSION CONTROL PROJECT, POLE CREEK}

$$
\text { (July 16, 1992) }
$$

\section{Site Description}

The review team visited a lower reach of Pole creek on the Henslee Ranch. The owners of the ranch had previously fenced major portions of Pole Creek from cattle grazing and the recovery of streamside vegetation was readily apparent. Furthermore, the efficiency of the ranch's irrigation system has been sufficiently improved such that nearly 7 cfs is again flowing down Pole creek. The management changes undertaken by the Henslee Ranch are commendable. They have increased the protection of Pole Creek from grazing, thereby allowing the recovery of riparian vegetation and narrowing of the channel, and have increased the amount of flow in Pole creek.

The erosion control project occurs upstream of the Henslee Ranch property. In 1990 a series of rock check dams (approximately 11 in total) were placed in an actively eroding channel that had deeply incised into valley bottom sediments. The channel incision apparently developed along an old sheep trail when water levels from Pole Creek was elevated by beaver dams. Much of the erosion apparently occurred during the high 
flows of 1986. The channel is relatively straight and continues through the meadow, terminating at an existing beaver pond. Some willow cuttings have been recently planted along the channel. The meadow is still being grazed.

\section{Observations/Interpretations/Comments}

Although the installation of structures has apparently stopped channel downcutting, the new channel and its associated structures are providing minimal fisheries values. Ultimately channel banks will stabilize, and beavers may eventually place dams in the newly formed channel. To aid this potential scenario, it is recommended that the entire riparian system be fenced to prohibit any future grazing.

Although directing flows back into the historic channel was considered during project design, the costs of doing so were apparently much greater than the current project which involved constructing a series of check dams in the newly eroding channel. Because the original channel undoubtedly had better fish habitat than the newly formed and relatively raw gully, we would have concluded that reestablishing flows into the original channel should have assumed a high priority.

The review team did not fully understand why reestablishing flows into the original channel was prohibitively expensive. This project represents an excellent example of where a onepage "fact sheet", which displays project costs and other project information, would have been extremely useful for evaluation purposes. 